International Journal of Advanced Chemistry, 9(2)(2021) 196-200
International Journal of Advanced Chemistry
SPC
Website: www.sciencepubco.com/index.php/IJET
Research paper

\title{
Anionic surfactant adsorption in detergent sewage with cation ion exchange method
}

\author{
Dewi Fernianti ${ }^{1 *}$, Wisnu $^{1}$ \\ ${ }^{I}$ Chemical Engineering, University of Muhammadiyah Palembang \\ *Corresponding author E-mail:ferniantidewi@gmail.com
}

\begin{abstract}
Surfactant is one of chemical substances added in detergent. The surfactant type added in detergent is anionic surfactant, namely Alkyl Benzene Sulfonate (ABS). Alkyl Benzene Sulfonate is a slow-degradable chemical substance due to branched chain in its structure, which causes low oxygen supply from the air due to foam covering the water surface. This condition can cause a dangerous impact for the organisms in the water.This study aimed to adsorb the anionic surfactant contained in detergent sewage using cation exchange resin. Before the adsorption process, cation resin regeneration process was performed following the standard operational procedures of PT. Pertamina RU III, Plaju using 4\% H2SO4solution at regeneration time of 45 minutes. Surfactant adsorption process occurred at room temperature with resin mass variables of 50,100, and $150 \mathrm{~g}$ and contact time of 5, 10, 15, 20, and 25 minutes. Furthermore, the surfactant content was analyzed using a spectrophotometer at $652 \mathrm{~nm}$ wavelength. The study analysis results showed that the adsorption process of anionic surfactant in the detergent sewage with cation ion exchange method at $50 \mathrm{~g}$ resin in $5-25$ minutes obtained a resin adsorption capacity of $0.72 \mathrm{~g}$, while $150 \mathrm{~g}$ resin at $5-25$ minutes only obtained a resin adsorption capacity of $0.18 \mathrm{~g}$. The best adsorption percentage was achieved from $150 \mathrm{~g}$ resin at a contact time of 25 minutes due to adsorbing the anionic surfactant up to $100 \%$. Meanwhile, the closest equation assessment approach was presented fromthe Langmuir adsorption isotherm model by gaining a linear graphic at R2 $=0.9946$.
\end{abstract}

Keywords: Resin; Cation Exchange; Surfcttant.

\section{Introduction}

Detergent is a cloth-cleaning material which is mostly used everyday in households and laundry business. The average of detergent used on each household is $50 \mathrm{~g} /$ day [1], while laundry business develops as people are more eager to practical lifestyle change. One of chemical substances added in detergent is surfactant. In general, 10-30\% surfactant is added in available commercial detergent products [2]. The surfactant type added in the detergent is anionic surfactant, namely Alkyl Benzene Sulfonate (ABS). Alkyl Benzene Sulfonate (ABS) is an anionic surfactant as its alkyl part is bonded with an anion.

Surfactant is added in detergent due to its capability in holding bubbles formed into the water after being shaken in a long time due to oil and water emulsion formation that can specifically remove the dirts [3]. The strong cleaning capacity is more favorable by the detergent users. However, alkyl benzene sulfonate is a slow-degradable chemical substance due to branched chain in its structure, which causes low oxygen supply from the air due to foam covering the water surface. This condition can cause a dangerous impact on the organisms in the water[4].

Several studies have been performed to determine the surfactant content of detergent sewage such asUtomo, P. Wahyu[5], who studied the decreased anionic and phosphate surfactant contents in Laundry sewage found in Keputih, Surabaya using an active carbon. The variables studied were composed of particle sizes, namely $-60,-120$, and -200 mesh. After the absorption process, the lowest surfactant content was found in -200 mesh particle at 3.102 ppm with an absent phosphate content. Selan, Th Fianelda[6]studied theReduction of Anionic Surfactant in Deterjent From Domestic Waste Water Using Pumice and Sand as a Media in Constructed Wetland System. The study results showed that the variation of $10 \%$ pumice and $90 \%$ sand obtained a surfactant content of $60.91 \%$.

Wibisono, I Candra[7]studied on the determination of Anionic Surfactant content inliquid-washing detergent using the Titrimetric method. Fernianti, dewi ${ }^{[8]}$ studied on the effect of detergent types and dilution ratio on the surfactant absorption process in detergent waste using an active carbon from tea solid waste. Based on the study results, the most optimum absorption capacity of detergent powder was obtained from the dilution ratio of $46 \mathrm{~g}$ in $2.5 \mathrm{~L}$ water at $5.133 \mathrm{mg} / \mathrm{l}$, while the dilution ratio of $10.5 \mathrm{~g}$ in $2.5 \mathrm{~L}$ water in liquid detergent obtained an absorption capacity of $5.056 \mathrm{ml} / \mathrm{l}$.

In this study, surfactant absorption in detergent sewage was performed through an adsorption method using a resin cation exchange. The adsorption process mechanism occurred by positive ion (cation) exchange, namely $\mathrm{Ca}, \mathrm{Mg}$, and $\mathrm{Na}$ through hydrogen resin (Resin $\mathrm{H}$ ) or Cation Exchanger as the exchange process is presented below: 


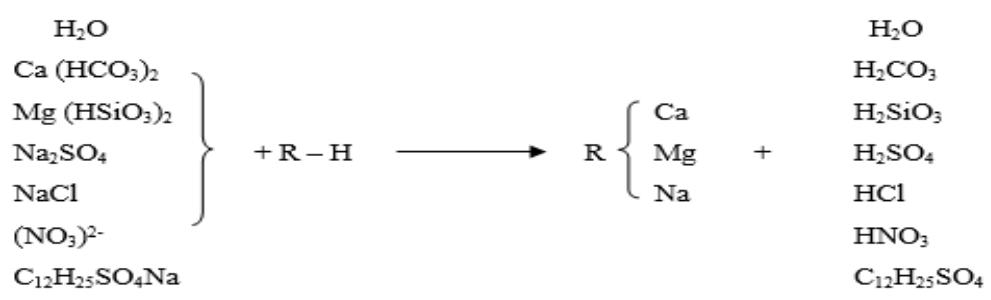

$\mathrm{R}$ is a symbol of resin material, while $\mathrm{R}-\mathrm{H}$ is an ion-exchanging resin as the capable exchanging ion is hydrogen (H). Salts in water will react to $\mathrm{H}$ released from $\mathrm{R}-\mathrm{H}$, while cations $(\mathrm{Ca}, \mathrm{Mg}, \mathrm{Na}$ ) replace the $\mathrm{H}$ position and bonded to resin. As cations in water is replaced by $\mathrm{H}$, an acidic solution is formed and solved in the water.

Adsorption isotherm explains the correlation of total adsorbent which occurs adsorption on the adsorbent surface during an equilibrium condition at a certain temperature [9].

Adsorption balance shows a correlation of solution concentration in solid phase (qe) and solution concentration in liquid phase (Ce).The adsorption equilibrium can be shown by the adsorption isotherm, namely:

Langmuir isotherm equation[10] :

$$
\mathrm{qe}=\frac{\mathrm{KqmCe}}{1+\mathrm{KCe}}
$$

The Langmuir isotherm equation can be written in a linear equation:

$$
\frac{\mathrm{Ce}}{\mathrm{qe}}=\frac{1}{\mathrm{qmK}}+\frac{\mathrm{Ce}}{\mathrm{qm}}
$$

This kinetic model of Langmuir adsorption is based on the assumption: Adsorption speed will depend on size factor and adsorbate molecular structure, solvent characteristics and adsorbent porosity, homogenous surface site and monolayer adsorption. Freundlichisotherm equation[10]

$\mathrm{q}_{\mathrm{e}}=\mathrm{kC}^{1 / \mathrm{n}}$

The Freundlich isotherm equation can be written in a linear equation:

$\log \mathrm{q}_{\mathrm{e}}=\frac{1}{\mathrm{n}} \log \mathrm{C}_{\mathrm{e}}+\log \mathrm{k}$

The Freundlichisotherm model explains the adsorption process in heterogeneous surfaceas not all adsorbent surfaces has an adsorption capacity. The Freundlichisotherm model indicates the adsorbate multilayer formed in adsorbent surface.

\section{Methods}

\subsection{Resin regeneration}

The resin used in this study was a former cation exchange resin used for the demineralization plant of PT. Pertamina RU III, Plaju. Before being used, this resin was regenerated. The cation resin regeneration followed the standard operation procedures of PT. Pertamina RU III,Plajusing $4 \% \mathrm{H}_{2} \mathrm{SO}_{4}$ solution with a regeneration time of 45 minutes.

\subsection{Surfactant adsorption process}

The $50 \mathrm{~g}$ regenerated cation resin was placed in a Beaker glass. The $200 \mathrm{ml}$ detergent solution was then added to the Beaker glass filled with cation resin. Beaker glass filled with cation resin and detergent solution was placed on the magnetic stirrer plate. The surfactant adsorption process was performed at room temperature for 5 minutes. After 5 minutes, the magnetic stirrer plate was turned off and the solution was filtered. The filtrate obtained was analyzed its surfactant content using a spectrophotometer at $652 \mathrm{~nm}$ wavelength. This procedure was repeated for 100 and $150 \mathrm{~g}$ cation resin with 10,15, 20, 25 minutes of adsorption time.

\section{Results and discussions}

\subsection{Results}

\subsubsection{Resin regeneration}

The resin used in this study was a former cation exchange resin used for the demineralization plant of PT. Pertamina RU III, Plaju, which was regenerated and analyzed its quality following the standard quality used by the PT Pertamina RU III Plaju. One of the indicators used for the former cation exchange resin is $\mathrm{pH}$. The regeneration result of former cation exchange resin can be seen atTable 1 below.

Table 1:Resin Specification After Regeneration

\begin{tabular}{llllll}
\hline Resin Mass $(\mathrm{g})$ & $\mathrm{H}_{2} \mathrm{SO}_{4}$ Volume $(\mathrm{mL})$ & $\mathrm{H}_{2} \mathrm{SO}_{4}$ Concentration $(\%)$ & Initial $\mathrm{pH}$ & Final $\mathrm{pH}$ & $\mathrm{pH}$ Standard Quality \\
\hline 500 & 500 & 4 & 6 & $1-3$ & 1.0 \\
500 & 500 & 4 & 6 & $1-3$ & 1.3 \\
500 & 500 & 4 & 6 & $1-3$ & 1.2 \\
\hline
\end{tabular}


From Table 1, the final pH result followed the standard quality of PT Pertamina RU III Plaju, namely pH of $1-3$.

3.1.2. Correlation betweenmass $(\mathrm{m})$ and time (t)on adsorbate mass per adsorbent mass unit (qe).

The correlation between mass $(\mathrm{m})$ and time ( $\mathrm{t}$ ) on the adsorbate mass per adsorbent mass unit (qe) can be seen in the following Graphic 1.

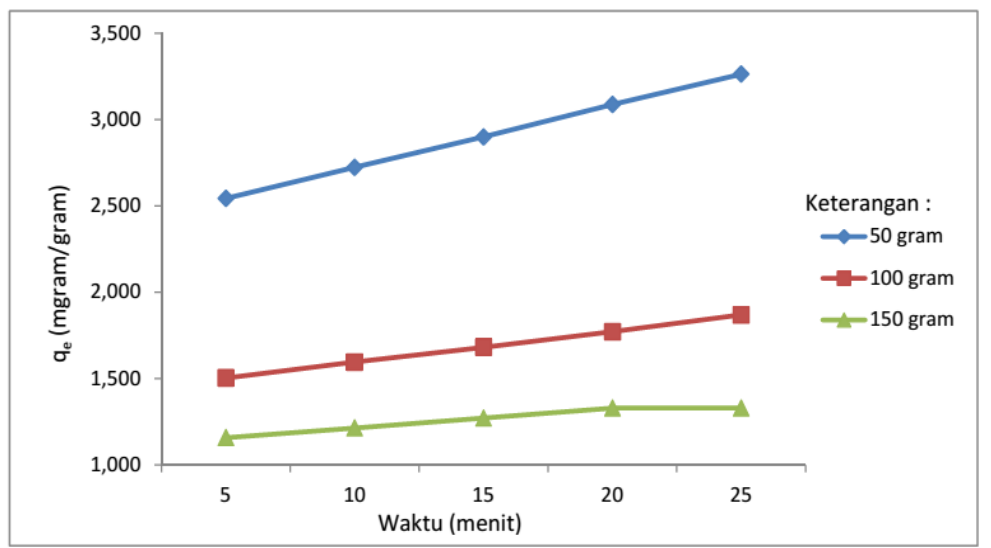

Graphic.1:The Correlation Between Mass and Time on Adsorbate Mass Per Adsorbent Mass Unit.

From graphic 1, resin mass remained unaffected on adsorbate mass per adsorbent mass unit.At 5 minutes and 50 g,adsorption capacity level continued to increase from 2.54 mgto $3.264 \mathrm{~g}$ at 25 minutes, while the adsorbate mass per absorbent mass unit at the same condition, namely 5 minutes and $150 \mathrm{~g}$ yaitu obtained $1.15 \mathrm{mg}$, which continued to increase until 25 minutes later at $1.33 \mathrm{~g}$.However, resin mass in a concentrated condition had no effect on the adsorbate mass per adsorbent mass unit. This condition was observed in $50 \mathrm{~g}$ on 5-25 minutes obtained a resin adsorption capacity at $0.72 \mathrm{~g}$, while $150 \mathrm{~g}$ resin on 5-25 minutes only obtained a resin adsorption capacity at $0.18 \mathrm{~g}$.

\subsubsection{Correlation between mass $(\mathrm{m})$ andtime $(\mathrm{t})$ on adsorption percentage $(\%)$}

The correlation between mass $(\mathrm{m})$ and time $(\mathrm{t})$ on the anionic surfactant adsorption percentage $(\%)$ can be seen in Graphic 2.

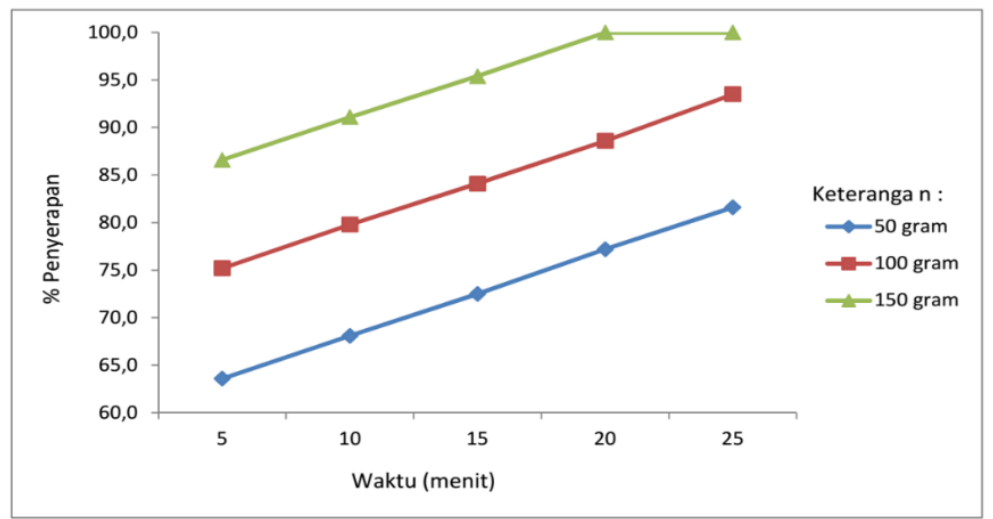

Graphic. 2: Correlation between Mass and Time on Adsorption Percentage.

From graphic 2, the correlation between adsorbent mass and time on the $\%$ of anionic surfactant adsorption was proportional as the more absorbent mass and the longer contact time, the higher $\%$ of anionic surfactant adsorption. For $50 \mathrm{~g}$ resin mass and 25 minutes of contact time, the adsorption capacity of anionic surfactant was $81.6 \%$, while the adsorption capacity reached $100 \%$ when the resin mass was 150 $\mathrm{g}$ with 20 minutes of contact time.This condition was caused as there was a force among molecules during adsorption process which provided R-H groupof resin could attract ion on the anionic surfactant to attach to the resin surface. The more resin mass, the wider resin surface, and the more anionic surfactant attached to the resin surface. Also, the longer contact time, the more intense interaction of molecules in the anionic surfactant.

\subsection{Analysis}

To observe the tendency towards adsorbate mass adsorbed by the adsorbent mass, an equation approach used in the adsorption isotherm process was Langmuiradsorption isotherm model and Freundlich adsorption isotherm model. The total adsorbate were defined in a linear equation[11].

\subsubsection{Correlation ofceonce / qe}

Langmuir adsorption isotherm is a monolayer adsorption which has a maximum capacity of adsorbent mass to represent the soluble adsorbate affinity on the absorbent [12]. 


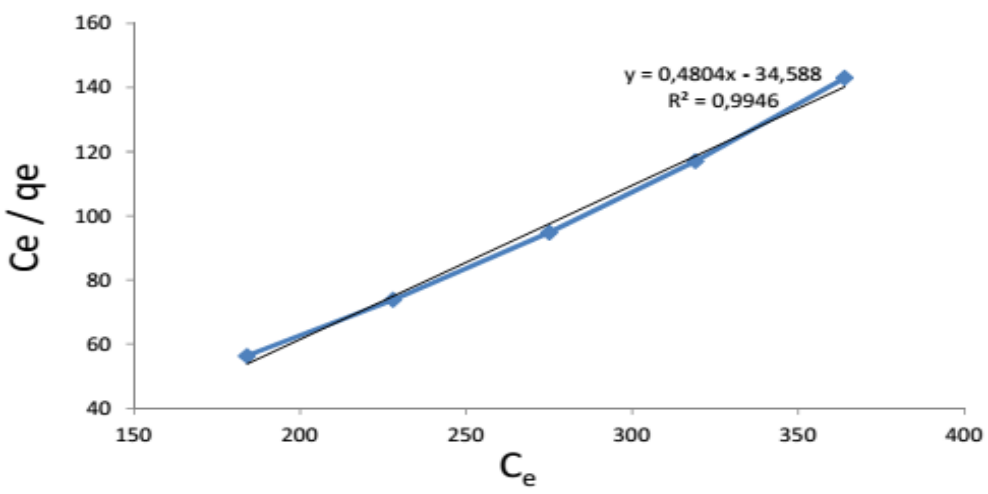

Graphic. 3:Correlation ofC $\mathrm{e}_{\mathrm{e}} \mathrm{onc}_{\mathrm{e}} / \mathrm{Q}_{\mathrm{e}}$ on Various Times.

From graphic 3, the assessment of anionic surfactant adsorption equation following the Langmuir equation obtained a good linear graphic with the value of $\mathrm{R}^{2}=0,9946$. This condition indicates that the adsorption process occurred between cation resin and anionic surfactant form a bond in the monolayer part.

\subsubsection{Correlation of $\log$ ceonlog qe}

The Freundlich adsorption isotherm is multilayer when the adsorbate occurs adsorption in a mass unit, which increases gradually as assumed that the adsorbent has heterogeneous surface and each molecule has different adsorption capacity[12].

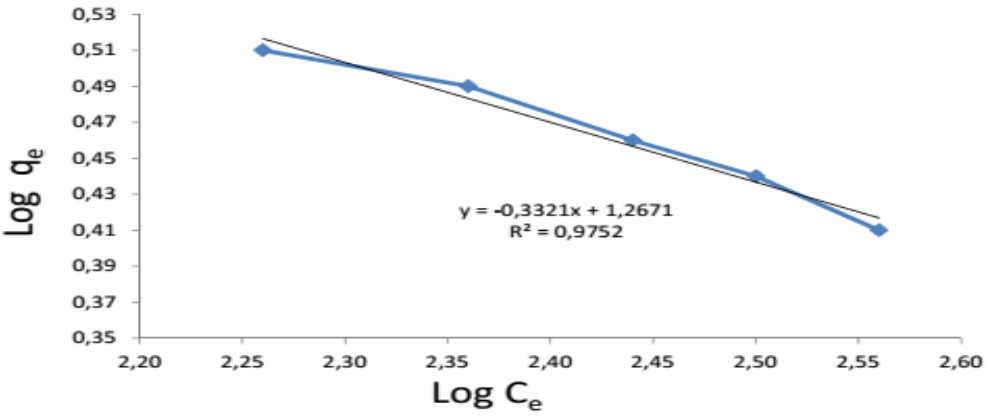

Graphic. 4:Correlation of $\log \mathrm{C}_{\mathrm{e}}$ onLog $\mathrm{q}_{\mathrm{e}}$.

From graphic 4, the assessment of anionic surfactant equation following theFreundlich equation obtained a good linear graphic with the value of $\mathrm{R}^{2}=0.9752$.this condition indicates that the adsorption process between cation resin and anionic surfactant form a bond in a multilayer part.

\section{Conclusions}

Based on the study results, it can be concluded that the anionic surfactant adsorption process in detergent sewage using the cation ion exchangemethod of $50 \mathrm{~g}$ resin mass and 5-25 minutes of contact time obtained resin adsorption capacity at $0.72 \mathrm{~g}$, while resin adsorption capacity only obtained $0.18 \mathrm{~g}$ for $150 \mathrm{~g}$ resin mass with 5-25 minutes of contact time. The best adsorption percentage was achieved on $150 \mathrm{~g}$ resin mass with 25 minutes of contact time due to capable of adsorbing the anionic surfactant up to $100 \%$.Meanwhile, the closest assessment approach was presented from the Langmuir adsorption isotherm model by gaining a good linearity graphic with the value of $\mathrm{R}^{2}=0,9946$.

\section{Acknowledgments}

Authors would like to thank the Head of Study Program for permitting this project to be carried out.

\section{References}

[1] https:// sustanation.id, “bahaya Deterjen Terhadap Lingkungan Rumah Tangga”, 12 desember 2018, dilihat Januari 20220.

[2] John Cross, 1998, “Anionic Surfactants Analytical Chemistry”, Second Edition, Marcell Dekkar Inc.

[3] https:// media neliti. Com, Juni 2021, dilihat Agustus 2021

[4] Connel and Miller, G.J, 1995, “ Kimia dan Ekotosiologi Pencemaran”, UI- Press, Jakarta.

[5] Wahyu P, Utomo, dkk, 2018, " Penurunan Kadar Surfaktan Anionik dan Fosfat Dalam Air Limbah Laundry di Kawasan Keputih SurabayaMenggunakan Karbon Aktif, AKTA KIMINDO, vol 3 (1), hal 127 -140, Depertemen Kimia, ITS, Surabaya.https://doi.org/10.12962/j25493736.v3i1.3528.

[6] Fianelda, T.S, dkk, 2020, "Reduction of Anionic Surfactant in Deterjent From Domestic Waste Water Using Pumice and Sand as a Media in Constructed Wetland Sytem “, Chem Note, 1 (1), 36-45, Prodi Fakultas Sains dan Teknik, Universitas Nusa Cendana Indonesia.

[7] Candra, IW, 2018, “Penetapan Kadar Surfaktan Anionik Pada Daterjen Cuci Cair Secara Metode Titrimetri”,ALKIMIA, Jurnal Ilmu Kimia dan Terapan, Vol 2 No.2, Fakultas Sains dan Teknik, UIN Raden Fatah, Palembang.https://doi.org/10.19109/alkimia.v2i2.2997.

[8] Fernianti, Dewi, 2017, “ Pengaruh Jenis Deterjen dan Rasio Pengenceran Terhadap Proses Penyerapan Surfaktan Dalam Limbah Deterjen Menggunakan Karbon Aktif Dari Ampas Teh", Jurnal Destilasi, Vol 2 No.2, Sept 2017, Prodi Teknik Kimia Fakultas Teknik Universitas Muhammadiyah Palembang.https://doi.org/10.32502/jd.v2i2.1147. 
[9] Obaid, S.A, “ Langmuir, Freundlich and Tamkin Adsorbtion Isoterm and Kinetics For Removal Aarlicheke Tournefortir Straw From Agricultural Waste, J.Phys Conf Set, vol 1664, hal 2020.https://doi.org/10.1088/1742-6596/1664/1/012011.

[10] Seader, J.D, Henley, E.J, 1998, “ Separation Process Principles”, New York, John Wiley and Sons.

[11] Khayun, T.S, and Mseer, A.H, 2019, Comparison of The Experiment Result With The Langmuir and Freundlich Models For Copper Removal On Limestone Adsorbent, Appl Water Sci, vol 9, No.8, pp 1-8.https://doi.org/10.1007/s13201-019-1061-2.

[12] Hyung-Kuen, Q, Kim, W,Park, J, Cho,J, Jeong, T and Park, P, 2015, Application of Langmuir and Freundlich Isothermis To Predict Adsorbate Removal Efficiency or Required Amount of Adsorbent “, J. Ind.Eng.Chem, pp 6-11.https://doi.org/10.1016/j.jiec.2015.02.021. 